\title{
THE PASSAGE INTO ETERNAL LIFE AND THE SEPARATION OF THE SOUL FROM THE BODY IN THE CHRISTIAN HYMNOGRAPHERS' THINKING
}

\author{
Ph.D. Cosmin Santi \\ Faculty of Orthodox Theology and Education Sciences, \\ „Valahia" University, Târgovişte, \\ ROMANIA, \\ E-mail: santicosmin@yahoo.com
}

\begin{abstract}
Immediately after death, the soul plunges into a light at the same time tender and lucid, allowing the soul to see his life again, to understand its innermost depths. It is that sensation of both wellness and pain that you experience every time a spiritually brilliant being is scrutinzing your soul, easily penetrating the ugliness of your character. This purifying sleep is not at all a state of unconsciousness. Death sets the person free from this leather costume in which we were enfolded the moment we went out of the paradisiac condition and by means of which we have been directed from transparent participation toward the universe. The shapes, the faculties, the senses of the body, aspired by the infinite, become interiorized and it is no longer the soul inside the body, but the body inside the soul. The senses that have become spiritualized, the perfect memory permit true personal meetings, not just between the dead, but also between the dead and the living. The place of these encounters can only be Christ, this centre toward Whom all the lines converge, Christ in Whom we are all one another's limbs. The prayer of the Church facilitates and accompanies the exode of the soul.
\end{abstract}

Keywords: hour of death; eternal life; soul; body; hymnography.

\section{INTRODUCTION}

The first truth confessed by our daily experience in a completely true manner is that necessarily we are all going to pass through death to the eternal life. We see it, we confess it, yet we do not believe it; the reason is that we would like to live forever, and what we want we hope for, because this thing is present in man since his creation, the soul being the one that, by the attribute of eternity, present in him, as image of God, wishes to attract the body as well into this immortality, man longing therefore after the paradisiac happiness, lost a long time ago, but brought back to us by our Savior Christ.

Death is the deepest and most significant fact of life, lifting even the last mortal over the day-to-day life and platitude. It is only death that raises the issue of the meaning of life, in its deepest sense. Life has meaning because there is death ${ }^{1}$. Death proves to be the only exit permitting the passage from the bad time into eternity, eternal life being accessible only by it. Consequently, man puts his last hope in it, where from the significance and the importance of death, but also its most prodigious paradox. Therefore, life is noble only

\footnotetext{
${ }^{1}$ Fr. Cosmin Santi, Eshatologia după cărţile de cult ortodoxe, Editura Galaxia Gutenberg, Târgu Lăpuş, 2012. p. 86 .
} 
because it supposes death, which testifies that man is meant for another life, a supreme life, without it the existence being an ordinary and absurd one. Between life in time and life in eternity there is a gap that cannot be crossed except by the act of death, by the anguish of the break-up.

The teaching of the 12 Apostles shows, regarding the way of death, that

„first of all it is bad and full of curse; crimes, adulteries, lust, debaucheries, trickeries, idolatries, witchcraft, charms, kidnappings, false testimonies, cheating, sneaky heart, slyness, pride, evilness, cheekiness, greed, profane words, envy, impudence, arrogance, self-importance, lack of fear; the people who belong to death are persecutes of the good ones, haters of the truth, lovers of lies; they do not know the reward of justice, they do not stick to goodness or to the good judgment; they are not vigilant for the good but for the bad; goodness and patience are far away from them; they love vanities, they look for bribes, they give no charity to the poor, they cannot stand those who are miserable, they do not know their Creator, they are killers of children, they ruin God's creature, turn their back on the needy, they oppress the one on the rocks; defenders of the rich, hypocrite judges of the poor, full of all sin",2.

Is man afraid of death? Yes and no, depending on how seriously he asked himself this question. In the past, the philosophers used to say that they are not afraid of death, but of its eternity, an erroneous thinking, because death is not eternal, but just a passage to an eternal life, good or bad, depending on the acts committed in the earthly life. The great philosopher Goethe once launched an idea according to which you die and become (Stirb und Werde), namely becoming by death ${ }^{3}$.

„Truly, awesome is the mystery of death, how the soul gets separated against his will from the joints, and, along with the being, the very natural connection, by the will of God, is severed. This is why we pray to Thee: those who have departed from us, give them rest in the tents of Your righteous ones, You, giver of life, Lover of men”“ „I keep crying and wailing when I think about death and I see in the tombs our beauty, the one created in the image of God, laying inert: awesome, without greatness and without a face. $\mathrm{O}$, wonder! What mystery is this, what has been done to us? How have we offered ourselves to rottenness? How have we taken upon us the yoke of death?"5.

\title{
2. THE HOUR OF DEATH, A MOMENT SEPARATING THE TEMPORAL FROM THE ETERNITY
}

Up to the eternal life, man has to go beyond the awesome hour of death, namely the concrete moment of the separation of the soul from the body, of the life from the body. There is fear of death because we are aware that beyond, there is no time and space, these two walking sticks we are using to drag ourselves along in life, and so, we mistakenly confuse the conscience of death with the fear of death. Yet, in order to learn how to die, you first need to learn how to live, taking the commandments and the advice of our Savior Christ and of His Church to be your guide.

\begin{abstract}
„The separation of the soul from the body is a frightening and awesome mystery for everyone; because the soul goes away weeping, while the body is covered, being given to the earth. Therefore, we, too, aware of the death of the body, let us run with tears to our Savior,
\end{abstract}

\footnotetext{
${ }^{2}$ Scrierile Părinţilor Apostolici, translation, notes and indexes by Fr. Dr. Dumitru Fecioru, Editura Institutului Biblic şi de Misiune al Bisericii Ortodoxe Române, Bucureşti, 1995, pp, 29-30.

${ }^{3}$ Dr. Mircea V. Homescu, Scrutând moartea... ca idee şi fenomen, in „Altarul Banatului”, XLIV (1994), no. 7 9, p. 13.

${ }^{4}$ Octoihul Mare, care cuprinde slujba Invierii pe opt glasuri, Tipografia cărţilor bisericeşti, Bucureşti, 1952 , Glasul al IV-lea, Sâmbătă dimineaţă, La Stihoavnă, Stihirile morţilor, Stihira I, p. 366.

${ }^{5}$ Molitfelnic, care cuprinde slujbe, rânduieli şi rugăciuni săvârşite de preot la diferite trebuinţe din viaţa creştinilor, Editura Institutului Biblic şi de Misiune al Bisericii Ortodoxe Române, Bucureşti, 2002, Rânduiala Înmormântării Mirenilor, Stihirile Sfântului Ioan Damaschin, Stihira a VIII-a, glasul al VIII-lea, p. 229.
} 
calling out: remember us, when You have come into Your kingdom”. ${ }^{6}$ „How am I spending my time carelessly? How am I wasting the time of my life with no vigilance, without taking into account my innumerable sins, or the dread of the fearful death and the incorruptible judgement? O, who shall save me from the eternal fire? Unless You were merciful to me, You Yourself all-good God"7.

At the hour of death, ,we shall need many prayers, many people to help us, many good deeds, much mediation from the angels, along our whole journey through the air. If when we go to a foreign country or an unknown city we need a guide, all the more we shall need guides and helpers to show us the way through the invisible hierarchies of angels of the air who are called persecutors and publicains and tax-collectors" ${ }^{\prime 8}$ (Saint John Chrysostom).

The hour of death is the beginning of immortality. To know and to accept that you will die is almost a virtue. How fine were our Italian ancestors feeling when they were saying: „Homo toties moritur, quoties amittit suos" ${ }^{9}$, namely ,man suffers as many deaths as he loses relations". This is why we, the Christians, are praying as follows:

\begin{abstract}
„Master Holder of Everything, God of our fathers and Lord of mercy, Maker of the mortal and of the immortal nation and of all the human nature, which is built and then destroyed again; Creator of life and of death, of the living here and of the passage to there; Who measures the years of life and orders the hour of death; Who takes to hell and out of it; Who binds into powerlessness and looses into power; Who orders the things of use here and usefully orders the things to come; Who has encouraged by the hope of resurrection those hurt by the pin of death, You Yourself, Master of all, God, our Savior, hope of all the margins of the earth"10. More often than not we accuse death of coming unexpectedly, of taking us by surprise. „You have gathered up no repentance, you, repentless soul, why are you delaying it? The separation of death and the end is drawing near; it has come as a thief",
\end{abstract}

Yet, it is not really so, because man, from the moment he is born, dies a little every day, and when death comes, it is but a final act, a moment of a stage that has been accompanying us throughout our life, as a poet was once beautifully saying „I am translating the breath of death right in the heart of death"12. True is the fact that man ought to die every day with Christ, killing the sin in him, and also resurrect each day with Christ, by faith and good deeds, to a new life of virtue. From this perspective, looking at life with the eyes of the man estranged from God, we consider death always too early for the young and too late for the old, which is not true; it is just our impression, an impression often pushing man to despair. We always need to pray as during the Holy Liturgy, with the prayer of the Litany, which says:

\footnotetext{
${ }^{6}$ Ibidem, Rânduiala Înmormântării Preoţilor şi a Diaconilor de mir, Fericirile, Stihira a III-a, glasul al II-lea, p. 273.

${ }^{7}$ Octoihul Mare, Glasul al VIII-lea, Duminică seara, la Doamne strigat-am, Stihirile de umilinţă, Stihira I, p. 651 .

8 Profeţii şi mărturii creştine pentru vremea de acum (selecţie de texte de la Sfinţii Părinţi şi autori contemporani), vol. 2, Editura Cartea Ortodoxă, Alexandria, 2006, pp. 116-117.

${ }^{9}$ Dr. Mircea V. Homescu, art.cit., pp. 14-17.

${ }^{10}$ Penticostarul, adică sfintele slujbe de la Duminica Paştilor până la Duminica Tuturor Sfinţilor, Editura Institutului Biblic şi de Misiune al Bisericii Ortodoxe Române, Bucureşti, 1999 Luni după Rusalii, la Vecernie, Rugăciunea a cincea, p. 334.

${ }^{11}$ Mineiul pe Iunie, Editura Reîntregirea, Alba-Iulia, 2001, Ziua a douăsprezecea, la Utrenie, la Stihoavnă, Şi acum..., glasul al VI-lea, p. 115.

${ }^{12}$ Dr. Mircea V. Homescu, art.cit., p. 18.
} 


\begin{abstract}
„A Christian ending to our life, painless, blameless, peaceful and a good defense before the dread Judgment Seat of Christ, let us ask"13.

But, the question is: if the memory of death is so useful for the soul, ,why doesn't God show to us the hour when we shall be leaving this world? If we knew when we would die, then we would be living in sin up to our last moment. And we would repent shortly before our death. As a result, however, we would be living in sins and would leave unjustified just as well. Similarly, if we had known the hour of our death, we would have died before our hour. Our life, while waiting for this dreadful moment, would have become tormented and unbearable. We can believe that we would not have been able to bear the knowledge of it. For this reason, God, Who loves man so much, out of His love for man, does not disclose to us the hour of our death"14.
\end{abstract}

\begin{abstract}
„O soul, the end is drawing near, and you are not taking care, you are not getting ready. Time is getting shorter, get up, the Judge is near the doors; as a dream, as a flower, the time of life is going away. Why are we agitating ourselves in vain?"15. „O my soul, o my soul, wake up, why are you asleep? The end is drawing near and you will grow anxious; but arise, so that Christ the Lord Who is everywhere and fulfils everything may have mercy on you"16. „Weep, shed tears, o soul, come back, repent; the day is near; the Judge is by the doors; get ready to answer and call out: I have done what is evil in Your sight, merciful, kindhearted, good God, have mercy on me"17.
\end{abstract}

Saint Gregory the Dialogist writes in his Homilies on the Evangels the following: „We need to think deeply about how dreadful the hour of death shall be for us, about the awe that will shroud our soul then, about how we will remember all our sins and we will forget all the joys, about the perspicacity of the Judge. Then the dirty spirits will sieve through all the acts of the soul of the deceased; then, they will put before him all the sins to which they pushed him, in order to prove him their accomplice in the work of unholiness. But why are we speaking only about the sinful soul, when they also come on the most elected of the mortals and try to claim their part of victory over them. Out of all men, only One has been able to state fearlessly, before His passions: „I will not speak with you much longer, for the ruler of this world is coming. He has no claim on Me" $(\text { John 14, 30 })^{18}$.

At the same time, God ordains when and how this moment will take place for each one of us, but God does not predestine us, on the contrary, man can freely choose to go one way or the other in life; God does nothing else but to take care of man by the act of His

\footnotetext{
${ }^{13}$ Liturghierul, care cuprinde dumnzeieştile liturghii ale sfinţilor noştri părinţi: Ioan Gură de Aur, Vasile cel Mare, şi Liturghia Darurilor mai înainte sfinţite, precum şi rânduiala Vecerniei, Utreniei, Dumnezeieştii Proscomidii, Liturghiei cu arhiereu etc., Editura Institutului Biblic şi de Misiune al Bisericii Ortodoxe Române, Bucureşti, 2012, Liturghia Sfântului Ioan Gură de Aur, Ectenia Cererilor, p. 210.

${ }^{14}$ Arhim. Vasiliu Bacoiani, Sufletul după moarte, translation by Țârlescu Ion Andrei, Editura Bunavestire, Galaţi, 2002, p. 20.

${ }^{15}$ Triodul, care cuprinde slujbele bisericeşti de la Duminica Vameşului şi Fariseului până la Sfânta Înviere, Editura Institutului Biblic şi de Misiune al Bisericii Ortodoxe Române, Bucureşti, 2000, Marţi în întâia săptămână a Sfântului şi Marelui Post, La Pavecerniţă, Canonul cel Mare alcătuire al Sfântului Părintelui nostru Andrei Criteanul Ierusalimiteanul, Cântarea a 4-a, Stihira a III-a, glasul al VI-lea, p. 131.

$16 * * *$, Ceaslov, ediţia a II-a, Editura Institutului Biblic şi de Misiune al Bisericii Ortodoxe Române, Bucureşti, 1993, Troparele şi Condacele Triodului, Joi, în a cincea săptămână a Marelui Postului, Condacul, Glasul al VIlea, p. 187.

${ }^{17}$ Triodul, Marţi dimineaţa în a doua săptămână a Sfântului şi Marelui Post, Tricântarea, Cântarea a 2-a, Stihira a II-a, glasul al VIII-lea, p. 224.

${ }^{18}$ Sfântul Grigorie Dialogul, Omilii la Evanghelii, 39 la Luca 19, $42-47$ apud Profeţii şi mărturii creştine pentru vremea de acum (selecţie de texte de la Sfinţii Părinţi şi autori contemporani), vol. 2, Editura Cartea Ortodoxă, Alexandria, 2006, p. 117.
} 
Providence, using the divine attributes, such as His Almightiness and His Omniscience, by which He knows the end of man as time and modality. For example, the martyrs' torments are apocalyptic. God defended Saint Eleftherios from many and dreadful torments: bed of fire, hungry lions, ashes ablaze, copper oven, to finally let him die a martyr's death, being beheaded. God could have stopped his executioner, yet His impenetrable wisdom judged that for the saint this moment and this way of dying are the most adequate for him to leave this world $^{19}$.

„Another world is waiting for You, o soul, and the Judge will disclose your hidden and bad things; therefore, do not remain in these things down here, but arise, saying to the Judge: God, have mercy on me and save me"20.

Saint John of Damascus says that when man reaches his last moment, he sees that he will get a reward for his actions: „People's actions are judged, according to their quality, in the balance, after man draws his last breath" 21 .

Therefore, ,thinking at the hour of the end, o soul, and fearing the cutting of the fig tree, diligently put to work the talent given to you, o wretched soul, being vigilant and saying: Let us not remain out of Christ's room ${ }^{22}$. „Alas, my darkened soul! Why won't you stop sinning? Why won't you put an end to your laziness? Why won't you remember the dreadful hour of death? Why won't you fear with your entire being our Savior's dread Judgment Seat? What do you want to say to defend yourself or how are you going to account for your acts? Your acts stand as a witness, rebuking you, your acts give you away, denouncing you. Therefore, o soul! Your time has come, run, arise and faithfully call out: Lord, I have done what is evil in Your sight; but I know, man-loving God, Your goodness; good Shepherd, do not send me away from Your right side, out of Your great mercy"23.

The soul, when the moment of its departure from the body is drawing near, goes through unsuspected and amazing trials:

$>$ fear of the unknown: by death, the soul settles himself alone in the other life, yet on his own he cannot pass into his abode, where he is to be living alone. Consequently, the soul is afraid of this unknown, his torments being moderated even since his departure from the body, when his company comes to see him off; the righteous is taken by the angels, the sinner is taken by the demons;

$>$ rapid separation: the body and the soul are like a couple in which the two love each other; therefore, when the separation moment comes, the soul cries and is in pain, does not want to leave the body, is separated hastily; it is the will of God for this couple to be destroyed, to be broken from the middle; ,at this moment man feels as if he were skinned alive, suffers as women do when labor time has come at child birth",24.

„Great crying and mourning, great weeping and hardship is the separation of the soul. Then come hell and perdition because of the transitory life, which is lifeless shadow, deceitful dream appearing like an illusion, the torment of life on earth. Let us run away from all earthly sin, to inherit the celestial things" 25 .,When the soul is kidnapped by force from the body, by scary angels, he forgets about all his relatives and acquaintances and is preoccupied by the future things, the judgments that will come on vanity and the much

\footnotetext{
${ }^{19}$ Arhim. Vasiliu Bacoiani, op.cit., pp. 21-22.

${ }^{20}$ Triodul, Stihiri de umilinţă, glasul I, Duminică seara, la Doamne Strigat-am, Stihira a III-a p. 695.

${ }^{21}$ Sfântul Ioan Damaschin apud Arhim. Vasiliu Bacoiani, op.cit., p. 12.

${ }^{22}$ Triodul, În Sfânta şi Marea zi Marţi în Săptămâna Patimilor, Denia de Luni seara, la Utrenie, Condac, glasul al II-lea, p. 559.

${ }^{23}$ Ibidem, Duminica Lăsatului sec de carne, La Vecernie-Sâmbătă Seara, la Stihoavnă, Slavă..., glas VIII, pp. 40-41.

${ }^{24}$ Cuv. Nichita Stithat apud. Arhim. Vasiliu Bacoiani, op.cit., p. 34

${ }^{25}$ Molitfelnic, Rânduiala Înmormântării Mirenilor, Stihirile, Stihira a V-a, glasul al II-lea, p. 237.
} 
tormented body" ${ }^{26}$. The Church has a special prayer for those whose soul comes out with difficulty: "Lord, unbind the soul of Your servant (Name) painlessly from his body..., and untie Your servant from this unbearable pain and bitter powerlessness..."27.

$>$ vision of demons: Demons are impatiently waiting for the last moments of our death. For them, this is the last and best chance to do harm to our soul. „The most awful darkness of death is troubling my soul, and the devils' claims always amaze and terrify me; save me from all these, good Bride of Christ, with Your might, Virgin not tempted by wedding, and set me on the shore of salvation and in the never setting light of the Saints" ${ }^{\prime 2}$. „Fearing the hour of the end and the terrible claims of the devils, I, a sinner, call out to You, with all my soul, with pain: Lord, my Master, by Your might crush their traps and barriers, and do not let Your servant fall a pray to their evilness. See my sadness and heed my trouble, and heal the pains of my wretched soul, most merciful God, Who bestows great mercy on the world” 29 . „Save, o Immaculate, my wretched soul, and have mercy on this soul, who is slipping, because of the multitude of sins, into the chasm of perdition, and at the dreadful hour of death, save me from the devils speaking evil of me, and save me from all torment" ${ }^{30}$.

It is important that, during the bitter moments of death, our man-loving God does not let man alone. Otherwise, man would sink in black despair, in depression. When man's soul comes out, man suffers, he is tormented. For this reason, during these moments, it is good to help the one in such a danger, by heartfelt prayer, by calling out to the All-good God. „Now weep for me, a wretched sinner, all the ends of the earth, and shed tears all together, because terrible decision has come from up high: that my hands and feet be tied together and that I be cast out” ${ }^{\prime 31}$. „Cry for me, weep for me, angelic hosts and you all, Christ-loving mortals, because, mercilessly, my soul is being separated from the body ${ }^{\prime \prime 2}$. „When You will please, o Immortal, to separate my soul from the bonds of the body, by Your command, then have mercy on me and send to me a kind angel with benevolent looks, to take me and defend me from the powers of darkness, to encourage me, so that I may travel easily straight up and arrive unpunished to Your dread Judgment Seat, to worship You, Allgood God"33.

For this reason, it is good for man to be prepared for the hour of death, by getting reconciled with those who have something against him, but especially by confessing his sins and partaking of the Holy Communion, because, little after the hour of death, he will go through unexpected trials: painful departure from the body, the terrible toll houses and the defense in front of our Lord Jesus Christ.

But there are moments when the soul does not come out easily and this state of fact torments man. This happens when the person lying on his death bed has been cursed by

\footnotetext{
${ }^{26}$ Ibidem, Stihira a VIII-a, glasul al II-lea, p. 238.

${ }^{27}$ Aghiasmatar, care cuprinde slujbe, rânduieli şi rugăciuni săvârşite de preot la diferite trebuinţe din viaţa creştinilor, Editura Institutului Biblic şi de Misiune al Bisericii Ortodoxe Române, Bucureşti, 2002, Slujba la ieşirea grea a sufletului, Rugăciune pentru cel ce se luptă greu cu moartea, p. 182.

${ }^{28}$ Octoihul Mare, Glasul al IV-lea, Marţi seară, la Doamne strigat-am, Stihirile Crucii, Stihira a VI-a, p. 321.

${ }^{29}$ Ibidem, Glasul al V-lea, Vineri seară, la Doamne Strigat-am, Stihirile de umilinţă, Stihira a II-a, p. 445.

${ }^{30}$ Ibidem, Glasul I, Polunoşniţa, Canonul Sfintei Treimi, Sedealna, Slavă... Şi acum..., p. 14.

${ }^{31}$ Molitfelnic, Slujba la ieşirea cu greu a sufletului, Canonul-alcătuire a lui Andrei al Cretei, Ierusalimiteanul, Cântarea a 8-a, Stihira I, glasul al VI-lea, p. 179.

${ }^{32}$ Ibidem, Cântarea a 4-a, Slavă, glasul al VI-lea, p. 176.

${ }^{33}$ Octoihul Mare, Glasul al VI-lea, Luni seară, la Doamne strigat-am, Stihiri de umilinţă, Stihira a III-a, p. 489.
} 
someone to have a bad end and, again, when God gives the person who is about to die a last chance of repentance ${ }^{34}$.

\begin{abstract}
„Poor me, for my unruliness! Alas for me, in my misery! For I hold out my hands to my friends and I shed tears from my eyes, but there is no one to have mercy on me" ${ }^{35}$. Yet, however, referring strictly to the hour of death, we need to have in view that, although all our life is a continual war on earth and we need to fight ceaselessly, until the end of our life, the most important day of our fight remains, nevertheless, the last hour of death, because whoever falls at that moment, will no longer get up. For this reason, this unique moment of man's life must find you as well prepared as possible to fight bravely. „Alas, there is so much fight for the soul when he gets separated from the body! Alas, how he sheds tears then and there is no one to have mercy on him at that time! Lifting his eyes to the angels, he prays in vain; holding out his hands to men, there is no one to help him"36.
\end{abstract}

The inimical devils have the habit of attacking at the moment of death by four dangerous claims: against faith, by despair, by vain glory and various imaginations and transformations of the devils into angels of light. If you are attacked against faith, do not let unfaithfulness slip into your heart, take out the intentions of the devil who wants, by war, to do you harm at that hour, and pray a long time to God and keep your heart strong and unshaken. Do not lose, by any means, your heart in those moments, because you will see in front of your eyes acts by which you offended God, you will see all your sins, and then ask God to forgive you and hope to obtain His forgiveness. But, at that hour, do not boast with vain glory, thinking about the good and beautiful deeds that you did in your life, because we are still "useless servants, having done only what we had to do" (Luke 17, 10).

It is only in this way that we shall be able to go over these hard trials, it is only in this way that we will weaken the enemy's power at the moment of death and, in this way, the way will be open to us to pass from this earth and exile to the heavenly Jerusalem ${ }^{37}$. „From now on I will no longer fear, Master Christ, the return into the earth, because You, by Your Resurrection, for Your great goodness, have lifted me, the forsaken one, from the earth to the height of incorruption, 38 .

About the hour of death, Saint Cyril of Alexandria speaks in detail in his discourse on the departure of the soul: ,What fright and torment are waiting for you, o soul, on the day of death! Then you will see the terrible, savage, cruel, merciless and shameless demons, like dark beings surrounding you. Just to see them is worse than any torment. The soul, seeing them, is filled with anguish, becomes disconcerted, struggles, tries to hide, and falls at the feet of God's Angels. The Holy Angels hold him; going with him through the air and moving up, they get to the toll houses guarding the road from earth to heaven and keeping the souls and preventing them from going higher ${ }^{39}$.

\footnotetext{
${ }^{34}$ Arhim. Vasiliu Bacoiani, op.cit., pp. 34-38.

${ }^{35}$ Molitfelnic, Slujba la ieşirea cu greu a sufletului, Canonul-alcătuire a lui Andrei al Cretei, Ierusalimiteanul, Cântarea a 4-a, Stihira I, glasul al VI-lea, p. 176.

${ }^{36}$ Ibidem, Rânduiala Înmormântării Mirenilor, Stihirile Sfântului Ioan Damaschin, Stihira a II-a, glasul al IIlea, p. 228.

${ }_{37}^{37}$ Sfântul Nicodim Aghioritul, Războiul nevăzut, Editura Egumeniţa, Galaţi, 2008, pp. 193-198.

${ }^{38}$ Octoihul Mare, Glasul al VI-lea, Duminică dimineaţă, alt Canon al Prea Sfintei de Dumnezeu Născătoare, Peasna a 5-a, Stihira a III-a, p. 471.

39 Sfântul Chiril al Alexandriei apud Sfântul Ignatie Brancianinov and Teofan Zăvorâtul, Cuvânt despre moarte, Editura Pelerinul Român, Oradea, 1993, p. 29.
} 
Regarding this moment, Saint Gregory of Nazianzus says: „One ought to live for the age to come and make this life a ceaseless remembrance of death"40.

Saint Athanasius the Great, in his turn, exhorts: „Every hour remember that you shall leave this place and every day have death in front of your eyes"41. And Saint John Climacus says: "Let the thought about death be with you both when you go to sleep and when you wake up" 42 . The Holy Fathers exhort us to live every day as if it were our last day.

Saint John Chrysostom sees the time of the hour of death as salvation for the soul, because "our body, before being destroyed, lets out the soul living in it as if from an old house about to collapse, for him to be placed again, with even more glory, in the new house that is being built" ${ }^{\text {"4 }}$. „Leaving everything else aside, o soul, think about your last hour and pay attention to yourself, getting ready for departure, for fear that death, coming unexpectedly, might take you by surprise, finding you unprepared. Therefore, pray to the Lord, forever vigilant and crying",44.

For the saints, this separation is easy and an occasion of joy. St. Theognostus says that ,the soul getting separated from the body full of confidence and taking it out as a jacket, experiences an ineffable and untranslatable joy. For, getting what he had been hoping for, he takes it out with no sadness"

\section{CONCLUSIONS}

The suffering and torment endured at the departure of the soul from the body are not always the sign of a sinful love for the body, of ,philautia”, ,the bad love for the body”, as Saint Maximus the Confessor calls it, and the root of all the sinful passions. First of all, there is the natural suffering produced by the tearing up of the human nature, which is breaking up into the parts from which it was created, consequently breaking up the unity of the human person ${ }^{46}$. „Alas, there is so much fight for the soul when it gets separated from the body! Alas, how he sheds tears then and there is no one to have mercy on him at that time! Lifting his eyes to the angels, he prays in vain; holding out his hands to men, there is no one to help him. Consequently, my beloved brothers, knowing the brevity of our life, let us ask from Christ: give rest to our departed ones, and have great mercy on our souls" ${ }^{\text {47 }}$. „Behold, now my soul is painfully getting separated from my miserable body. Therefore, do not bury it in the ground, for it is not worthy of it; but, dragging it out, throw it to the dogs"

\footnotetext{
40 Sfântul Grigorie de Nazianz apud Jean-Claude Larchet, Creştinul în faţa bolii, suferinţei şi a morţii, translation from French by Marinela Bojin, Editura Sofia, Bucureşti, 2006, p. 234.

${ }^{41}$ Sfântul Atanasie cel Mare apud Jean-Claude Larchet, Creştinul în faţa bolii, suferinţei şi a morţii, translation from French by Marinela Bojin, Editura Sofia, Bucureşti, 2006, p. 235.

${ }^{42}$ Sfântul Ioan Scărarul apud Jean-Claude Larchet, Creştinul în faţa bolii, suferinţei şi a morţii, translation from French by Marinela Bojin, Editura Sofia, Bucureşti, 2006, p. 235.

${ }^{43}$ Sfântul Ioan Gură de Aur, Problemele vieţii, translation by Cristian Spătărelu and Daniela Filioreanu, Editura Cartea Ortodoxă-Egumeniţa, Galaţi, 2007, pp. 92-93.

${ }^{44}$ Octoihul Mare, Glasul I, Vineri seară, la Doamne Strigat-am, Stihira a II-a, p. 87.

${ }^{45}$ Sfântul Teognost, Capete despre făptuire şi vedere, 61 apud Jean-Claude Larchet, Tradiţia Ortodoxă despre viaţa de după moarte, translation from French by Marinela Bojin, Editura Sofia, Bucureşti, 2006, p. 75.

${ }^{46}$ Jean-Claude Larchet, Tradiţia Ortodoxă despre viaţa de după moarte, translation from French by Marinela Bojin, Editura Sofia, Bucureşti, 2006, p. 75.

47 Triodul, Stihiri de umilinţă, glasul al II-lea, Vineri seara, la Doamne strigat-am, Slavă... a morţilor, alcătuire a lui Ioan Damaschin, p. 705.

${ }^{48}$ Molitfelnic, Slujba la ieşirea cu greu a sufletului, Canonul-alcătuire a lui Andrei al Cretei, Ierusalimiteanul, Cântarea a 6-a, Stihira a II-a, glasul al VI-lea, p. 177.
} 
We need to understand that man's life on this earth is short and getting shorter day by day. Yet, the future life has no end. As the soul goes over the threshold of death, so he will enter the eternity, at the end of ages. For this reason, man needs to get ready for the eternity awaiting for him, sparing no effort and no time. At the hour of death, there is no time for thinking and preparation; this work is the work of a whole life, moment by moment. Just as a lamp cannot give light without oil, similarly a Christian cannot enter the Kingdom without the oil of good deeds. And he must be vigilant that this oil may never be missing from him, so that he may not be like the crazy virgins, who were not sent to the wedding room (Matthew 25, 1-13). Therefore stay alert, because you know neither the day nor the hour (Matthew 25, 13). The preparation for the eternal life will not take place in a moment and the weeping of the hour of death is not enough, although man's repentance and return to God at the last hour have their value ${ }^{49}$. "You Who will come and judge the human nation, most righteous Judge, in the dread hour, do not send me condemned in the fire of the

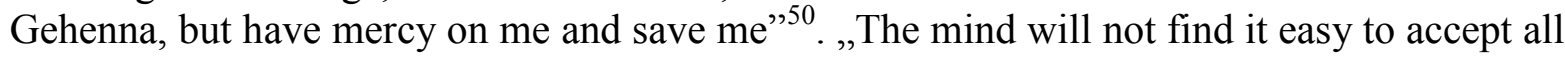
these... Yet a faith able to prevail over the weaknesses of the mind will believe and receive this truth" ${ }^{, 51}$. „It is specific of faith to believe even in things it has not seen yet" ${ }^{, 52}$. „Eternal life is the fruit and the crown of faith in Christ and the latter will come in no other way to the human soul",53.

At the funeral service we hear the exhortation: „Come and behold, all of you, the alien and frightening sight known to all, the vision showing itself now, and no longer think about the transitory things, because today the soul is getting separated from the body, moving into the eternal world, going a way it has never walked before, and to the incorruptible Judge, in the presence of the angelical hosts; and dreadful is that judgment where we shall all be seen naked: some ashamed, others crowned",54.

„Maybe many of those who believe, but do not have an unshaking and confident faith are so that one can say about them that they have faith in Christ and that they will receive death and will die some time. Yet, dying they will not remain in death, but will win life. However, whoever, having acquired steadiness and confidence, has faith as his habit is truly alive and faithful and shall never die" ${ }^{55}$ (Saint Cyril of Alexandria).

Consequently, death is the birth of man from the transitory earthly life into the eternal life. During the accomplishment of the mystery of death, we shed our body, and with our thin, esoteric spiritual being, we pass into another world, on the realm of the beings of the same kind as the souls. The soul departed from the body is invisible and inaccessible, all we can see being only the body suddenly emptied of life, or the inanimation of the time when the mystery of death occurs. Any man has the experience of death. Far from avoiding

\footnotetext{
${ }^{49}$ Jean-Claude Larchet, Creştinul în faţa bolii, suferinţei şi a morţii, translation from French by Marinela Bojin, Editura Sofia, Bucureşti, 2006, pp. 237-238.

${ }^{50}$ Octoihul Mare, Glasul al I-lea, Marţi dimineaţă, alt Canon al Sfântului Ioan Botezătorul, Peasna a 8-a, Stihira a III-a, p. 50.

${ }^{51}$ Sfântul Ioan Gură de Aur, Comentar la Evanghelia de la Ioan apud Fr. Conf. Dr. Petre Comşa, Sfinţii Părinţi, acoperământul propovăduirii, Editura ASA, Bucureşti, 2006, p. 169.

${ }^{52}$ Ibidem

53 Sfântul Chiril al Alexandriei, Comentariu la Evanghelia Sfântului Ioan apud Fr. Conf. Dr. Petre Comşa, Sfinţii Părinţi, acoperământul propovăduirii, Editura ASA, Bucureşti, 2006, p. 169.

${ }^{54}$ Molitfelnic, Rânduiala Înmormântării Preoţilor şi a Diaconilor de mir, după Laude, alte stihiri idiomele, Slavă..., glasul al VI-lea, p. 297.

55 Sfântul Chiril al Alexandriei, Comentariu la Evanghelia Sfântului Ioan apud Fr. Conf. Dr. Petre Comşa, Sfinţii Părinţi, acoperământul propovăduirii, Editura ASA, Bucureşti, 2006, p. 169.
} 
reality, taking refuge in illusory dreams, the biblical revelation, regardless of its stages that we choose to examine, begins by looking it in the face with lucidity: the death of our dear ones, which, once the goodbye moments are over, brings sorrow in the hearts of those left behind (Genesis 50, 1); death awaits everyone, for everyone will see death (Psalm 89,49; Luke 2, 26; John 8, 51). Death is the common lot of all the people, the way of all flesh (1 Kings 2,2). Yet, we have Christ's victory over death, which is a victory over death and corruption, as physical phenomena; it is a victory over sin and sinful passions, triggered and amplified by the specter of death. Its meaning will not become clear except at the end of the centuries, at the general resurrection. By the redeeming work of Christ, the punishment of death has been lifted. There will still be death until the general resurrection, at the end of the centuries, yet it no longer rules over those united with Christ by the Holy Mysteries and by the accomplishment of His divine commandments. The bodies still die, yet death is no longer annihilation, but rest. Therefore, in the supreme act of our Lord Christ, an act of victory over death, and in His Resurrection from the dead, we do not see only the simple resurrection of the man Jesus, but our wonderful, real and definitive passage in the Christ crucified and resurrected from ,death to life, from the earth to heaven", the moment of the resurrection of the dead, the passage to the eternal life, a fundamental, spiritual passage of the whole world into another level of existence, into the new immortal life of communion with the resurrected Christ and, in Him and by Him, with the entire Holy Trinity: „We worship You Immaculate, Good One, asking You to forgive our sins, Christ our Lord; because willingly You have agreed to be lifted with Your body on the cross to save Your creatures from the slavery of the enemy. For this, we thankfully say to You: You have filled everything with joy, our Savior, Who have come to redeem the world"56.

\section{BIBLIOGRAPHY}

[1] ***, Biblia sau Sfânta Scriptură, tipărită sub îndrumarea şi cu purtarea de grijă a Prea Fericitului Părinte DANIEL - Patriarhul Bisericii Ortodoxe Române, Editura Institutului Biblic şi de Misiune al Bisericii Ortodoxe Române, Bucureşti, 2008.

[2] Bacoiani, Arhim. Vasiliu, Sufletul după moarte, translation by Țârlescu Ion Andrei, Editura Bunavestire, Galaţi, 2002.

[3] Comşa, Fr. Conf. Dr. Petre, Sfinţii Părinţi, acoperământul propovăduirii, Editura ASA, Bucureşti, 2006.

[4] Homescu, Dr. Mircea V., Scrutând moartea... ca idee şi fenomen, in „Altarul Banatului”, XLIV (1994), no. 7-9.

[5] Larchet, Jean-Claude, Creştinul în faţa bolii, suferinţei şi a morţii, translation from French by Marinela Bojin, Editura Sofia, Bucureşti, 2006.

[6] Idem, Tradiţia Ortodoxă despre viaţa de după moarte, translation from French by Marinela Bojin, Editura Sofia, Bucureşti, 2006.

[7] Santi, Fr. Cosmin, Eshatologia după cărţile de cult ortodoxe, Editura Galaxia Gutenberg, Târgu Lăpuş, 2012.

[8] Sfântul Ioan Gură de Aur, Problemele vieţii, translation by Cristian Spătărelu and Daniela Filioreanu, Editura Cartea Ortodoxă-Egumeniţa, Galaţi, 2007.

[9] Sfântul Ignatie Brancianinov and Teofan Zăvorâtul, Cuvânt despre moarte, Editura Pelerinul Român, Oradea, 1993.

[10] Sfântul Nicodim Aghioritul, Războiul nevăzut, Editura Egumeniţa, Galaţi, 2008.

[11]***, Aghiasmatar, care cuprinde slujbe, rânduieli şi rugăciuni săvârşite de preot la diferite trebuinţe din viaţa creştinilor, Editura Institutului Biblic şi de Misiune al Bisericii Ortodoxe Române, Bucureşti, 2002.

56 ***, Penticostarul, Joi în săptămâna a treia după Paşti, la Utrenie, după întâia Catismă, Sedelnele, Sedealna Crucii, glasul al II-lea, p. 122. 
[12]***, Ceaslov, ediţia a II-a, Editura Institutului Biblic şi de Misiune al Bisericii Ortodoxe Române, Bucureşti, 1993, Troparele şi Condacele Triodului, Joi, în a cincea săptămână a Marelui Postului, Condacul, Glasul al VI-lea, p. 187.

[13]***, Liturghierul, care cuprinde dumnzeieştile liturghii ale sfinţilor noştri părinţi: Ioan Gură de Aur, Vasile cel Mare, şi Liturghia Darurilor mai înainte sfinţite, precum şi rânduiala Vecerniei, Utreniei, Dumnezeieştii Proscomidii, Liturghiei cu arhiereu etc., Editura Institutului Biblic şi de Misiune al Bisericii Ortodoxe Române, Bucureşti, 2012.

[14]***, Mineiul pe Iunie, Editura Reîntregirea, Alba-Iulia, 2001.

[15]***, Molitfelnic, care cuprinde slujbe, rânduieli şi rugăciuni săvârşite de preot la diferite trebuinţe din viaţa creştinilor, Editura Institutului Biblic şi de Misiune al Bisericii Ortodoxe Române, Bucureşti, 2002.

[16] ***, Octoihul Mare, care cuprinde slujba Învierii pe opt glasuri, Tipografia cărţilor bisericeşti, Bucureşti, 1952.

[17]***, Penticostarul, adică sfintele slujbe de la Duminica Paştilor până la Duminica Tuturor Sfinţilor, Editura Institutului Biblic şi de Misiune al Bisericii Ortodoxe Române, Bucureşti, 1999.

[18]***, Profeţii şi mărturii creştine pentru vremea de acum (selecţie de texte de la Sfinţii Părinţi şi autori contemporani), vol. 2, Editura Cartea Ortodoxă, Alexandria, 2006.

[19]***, Scrierile Părinţilor Apostolici, translation, notes and indexes by Fr. Dr. Dumitru Fecioru, Editura Institutului Biblic şi de Misiune al Bisericii Ortodoxe Române, Bucureşti, 1995.

[20] ***, Triodul, care cuprinde slujbele bisericeşti de la Duminica Vameşului şi Fariseului până la Sfânta Înviere, Editura Institutului Biblic şi de Misiune al Bisericii Ortodoxe Române, Bucureşti, 2000. 